\title{
Introduction: John Morrill and the experience of revolution
}

\author{
Michael F. Braddick and David L. Smith
}

\section{I}

When John Morrill began his research career the most influential writing about mid-seventeenth-century England was essentially concerned with modernization, and, even in non-Marxist explanations, contained a strong strain of materialism. This was a prominent feature of the sometimes vituperative exchanges of the gentry debate, and John's first piece of extended writing about seventeenth-century England was written in response to that controversy; it was a long essay, composed during a summer vacation, which examined the relationship between the fortunes of particular gentry families and their Civil War allegiance. His interest in local realities, however, quickly gave rise to dissatisfaction with the broad categories of analysis with which the gentry controversy was engaged. By the time that he published the monograph based on his Oxford D.Phil. thesis, in 1974, he concluded (among other things) that 'the particular situation in Cheshire diffracted the conflicts between King and Parliament into an individual and specific pattern. As a result all rigid, generalized explanations, particularly of the socio-economic kind, are unhelpful if not downright misleading. ${ }^{\text {, }}$ A desire to do better than these generalizations has driven his work ever since, and has thereby provided a huge stimulus to scholars of early modern England.

His doctoral study of Cheshire marked the beginning of the first of three overlapping but distinct phases in the development of his work, in each of which he has been a leading figure. All have been a point of reference for the work of numerous scholars engaged in a critical reappraisal of the Whig and Marxist traditions. In his first phase, as a local historian,

1 J. S. Morrill, Cheshire, 1630-1660: County Government and Society during the 'English Revolution' (Oxford, 1974), p. 330. He later distanced himself a little from this position: see John Morrill, Revolt in the Provinces: The People of England and the Tragedies of War, 1630-1648, 2nd edn (Harlow, 1999), especially p. 17. This Introduction should be read alongside the chronological bibliography of John's major writings at pp. 291-8. This bibliography obviates the need for detailed footnotes here, except to provide references for specific quotations. 
John followed the lead given by Alan Everitt, and helped to breathe new life into a nineteenth-century genre of county histories, while stimulating a veritable research industry in the production of county studies. His own summary of much of this work, The Revolt of the Provinces, was published in 1976 and proved a seminal work, synthesizing John's own research with the large number of local studies that had appeared over the previous decade. In doing so, it offered a new explanation of the political, as opposed to social, conflicts that emerged in the reign of Charles I. The essence of John's argument was that 'England at this period is more like a federated state than a unitary national state', and that 'national issues took on different resonances in each local context and became intricately bound up with purely local issues and groupings'. ${ }^{2}$ The titles of John's publications between the early 1970s and the early 1980s reflected this preoccupation with the local dimension, and especially with the dilemmas of that 'silent majority' 3 who strove to keep the Civil War out of their locality.

This view of the nature of the political relationship between centre and locality has been much revised in the last thirty-five years. ${ }^{4}$ John's work has been criticized for underestimating the importance of political engagement in local societies, and for taking the ideology out of the Civil War and the Revolution. At a greater distance in time, however, it seems more accurate to suggest that the significance of neutralism and attempts to disengage from armed conflict were a means both to emphasize the importance of local commitments and an attempt to bring into sharper focus those issues which overrode that essential commitment. In any case, by 1981 he had come to feel that he "had said all [he] wanted to say about "neutralism" and "localism". 5 In fact, the important and influential

2 J. S. Morrill, Seventeenth-Century Britain, 1603-1714 (Folkestone, 1980), p. 125; A. M. Everitt, The Community of Kent and the Great Rebellion, 1640-60 (Leicester, 1966); A. M. Everitt, The Local Community and the Great Rebellion, Historical Association, General Series 70 (1969), repr. in R. C. Richardson, ed., The English Civil Wars: Local Aspects (Stroud, 1997), pp. 14-36.

3 J. S. Morrill, 'William Davenport and the "silent majority" of early Stuart England', Fournal of the Chester and North Wales Archaeological Society, 58 (1975), 115-29.

4 Clive Holmes, 'The county community in Stuart historiography', fournal of British Studies, 19 (1980), 54-73; Ann Hughes, 'Local history and the origins of the Civil War', in Richard Cust and Ann Hughes, eds., Conflict in Early Stuart England (Harlow, 1989), pp. 224-53; Clive Holmes, 'Centre and locality in civil-war England', in John Adamson, ed., The English Civil War (Basingstoke, 2009), pp. 153-74.

5 John Morrill, The Nature of the English Revolution (Harlow, 1993), p. 34. So effective was the stimulus to this kind of work that in 1984 his advice to Braddick was 'Whatever you do, don't do a county study'. John has subsequently acknowledged the limitations of the localist approach, while also restating and refining his argument: Morrill, Nature, pp. 179-90; Morrill, Revolt in the Provinces, pp. 1-23, 177-208. 
body of work associated with his 'localist' phase already contained the seeds of John's second major historiographical contribution. In The Revolt of the Provinces, published in 1976, he wrote: 'while the great majority of men dithered or wrote petitions and talked of raising a third force for peace, it was the men who felt most strongly about religion who began the war'. ${ }^{6}$ His emphasis on localism threw into sharp relief the difficulty of the choices people made at the outbreak of the war, as they tried to reconcile apparently contradictory impulses and commitments in order to make the 'agonizing' choices which events were forcing upon them.

From this position John famously presented in a lecture to the Royal Historical Society in December 1983 the thesis that 'The English Civil War was not the first European revolution: it was the last of the Wars of Religion'. ${ }^{7}$ The importance of religion in shaping seventeenth-century British history has been a central theme in much of John's subsequent work. He has acknowledged the problems of the term 'war of religion', but the significance of religious issues both in the lives of individual historical figures (such as Oliver Cromwell or William Dowsing) and in driving the course of events has remained central to his writings ever since. As he put it in an essay published in 2008, 'these were wars of religion as much as any wars in early modern Europe were wars of religion that is to say, they were about many things other than religion, but confessional poles were those around which all kinds of other issues clustered'. 9

The stimulus of this second creative departure in his understanding of the Civil War is still very much with us, and many of the essays in this collection engage with these questions. In particular, those by Glenn Burgess (Ph.D. 1988), David Smith (Ph.D. 1990), Ian Atherton (Ph.D. 1993) and Anthony Milton (Ph.D. 1989) all reflect in one way or another on the utility of interpreting these events as a war, or wars, of religion. Glenn Burgess's essay pursues the question of historical change, and the place of the Revolution in a longer history, through an examination of the thought of four individuals. For Stephen Marshall, Henry Ireton, Jasper Mayne and John Locke a key question posed by the experience

6 J. S. Morrill, The Revolt of the Provinces: Conservatives and Radicals in the English Civil War, 1630-1650 (1976), p. 50.

7 Morrill, Nature, p. 68. This lecture, entitled 'The religious context of the English civil war', was first published in Transactions of the Royal Historical Society, 5th ser., 34 (1984), 155-78, and later reprinted in Morrill, Nature, pp. 45-68.

8 See especially Morrill, Nature, pp. 33-44.

9 John Morrill, 'The rule of saints and soldiers: the wars of religion in Britain and Ireland, 1638-1660', in Jenny Wormald, ed., The Short Oxford History of the British Isles: The Seventeenth Century (Oxford, 2008), pp. 83-115, at p. 84. 
of revolution was 'could civil society survive the religious enthusiasm of its subjects (and its rulers)?'. All of them were forced to reflect on the relationship between the commitments of religious conscience and other social goods - in particular the role of law and the importance of civil peace. They, and others, 'were compelled to ask how civil society could survive among a diversity of religious beliefs' even if 'they were not compelled to agree on the answers'. In exploring the interaction between the political and religious dimensions of social life, these authors sometimes made secularizing moves - shifting the boundary in some respect so as to better secure civil peace - but none of them had a properly secularizing intent. All remained convinced of the public and political importance of religion; the difficulty they addressed was how to secure that without jeopardizing the stability of civil society.

These complexities are often best understood through the study of particular individuals. It is in this way that we get a sense of what was flexible and what was immoveable. David Smith examines the development of Sir Benjamin Rudyerd's political positions in the course of his long parliamentary career. There are strong consistencies in Rudyerd's commitment to godly reformation and to a strong relationship between crown and parliament based on trust (which implied adequate financial supply for the crown). His silver-tongued advocacy of these principles was remarkably consistent from the 1620 s to the end of his career, and they supported a clear Parliamentarian allegiance in the Civil War, but they were difficult to sustain in the light of events. As further reformation threatened disorder in the early 1640s, for example, he became a defender of episcopacy, but not a Royalist; and throughout the war he supported attempts to make peace. At the core of this analysis lie two concerns which are also characteristic of Morrill's work: the place of specifically religious sentiments in shaping Rudyerd's attitudes and actions, and a desire to understand what was consistent and what was malleable about his politics - what constituted his essential psychology and what proved more flexible in the face of events.

The role of religious issues and motives is likewise examined in Anthony Milton's essay, which explores the content of the religious advice addressed to Charles, how it reacted to the immediate needs of particular moments, and how it seems to have been reflected in Charles's negotiating positions. Here was a group of highly principled and conscientious people seeking to respond to circumstances, maintaining what had to be maintained and giving away as little as possible of what was disposable. It reveals how this was a war of religion not just for the radical Puritans, but also for those with a higher view of the Church of England and its future. 
Ian Atherton's essay explores the place of the cathedral in these arguments about the present and future of the English, Scottish and Irish churches. The practical complexity of reforming the church - the potentially competing pressures of local sentiment, legal right and reforming zeal, for example - are central to an explanation for the survival of the cathedrals, and their rapid re-establishment in 1660. What they came to represent for Parliamentarians and Royalists in the meantime also casts considerable light on some of the central issues of the Revolution, and on the differences between the wars of religion as they were experienced in the three kingdoms.

This focus on the three kingdoms brings us to the third major historiographical contribution that John has made, namely to encourage awareness of the importance of the 'British problem'. John's interest in what had prevented settlement, what in the politics of the crisis could not easily be negotiated, also informed his commitment to understanding the crisis in a British context. From about 1990 onwards, the titles of many of John's publications indicate a growing interest in the histories of Scotland and (especially) Ireland, and the ways in which those kingdoms interacted with England within the Stuart monarchies. This growing preoccupation is reflected in the fact that when John was elected to a Readership in the Cambridge History Faculty in 1992 he chose the title 'Reader in Early Modern History', but when six years later he was promoted to a personal chair he took the title 'Professor of British and Irish History'. John's key claim here is that 'some of the most stubborn and insoluble problems in the history of each kingdom require a British dimension in order to be fully understood'. He has therefore sought to reconstruct 'the story of three kingdoms in search of a defined relationship one to another, of four or more peoples in the process of refashioning themselves in the light of much heightened contact and friction'. ${ }^{10} \mathrm{He}$ wrote that in 1996, and many of his publications since then have explored the challenges and problems of constructing British history. As he put it in 2006, 'British history is . . . a story of not what is, or even what was, but what was in the process of becoming. ${ }^{11}$ Here he was influenced by the work of John Elliott and Conrad Russell, which understood seventeenthcentury political instability in structural terms, but as distinctively early modern phenomena, namely those associated with the problems of

10 John Morrill, 'The British problem, c. 1534-1707', in Brendan Bradshaw and John Morrill, eds., The British Problem, c. 1534-1707: State Formation in the Atlantic Archipelago (1996), pp. 1-38, at pp. 1-2.

11 John Morrill, 'Thinking about the New British History', in David Armitage, ed., British Political Thought in History, Literature and Theory, 1500-1800 (Cambridge, 2006), pp. 23-46, at p. 42. 
multiple kingdoms and composite monarchies or (John's term for the Stuart kingdoms) 'dynastic agglomerates' ${ }^{12}$

This body of work has also had a galvanizing effect on the field, a stimulus which is again reflected in the essays collected here. Joong-Lak Kim's (Ph.D. 1997) view of the Scottish Prayer Book depends on this extra-national perspective. Reconstructing both who was involved at each stage and what changes were introduced, he is able to build an argument about the direction and motives of reform. It was natural and plausible for Scots to see the Book as an effort at Anglicization, but by taking a cross-border view it is possible to see the Book as part of a programme for uniformity that would have required change in all three Churches. Here the influence of Laud and, behind him, Charles seems to have been crucial. For the framers of the Book, no less than those offended by it, the changes to the Scottish liturgy had to be understood in a British or three kingdoms perspective.

John McCafferty's (Ph.D. 1996) study of the life-writings about dead bishops reveals that the bishops appeared differently to readers in each of the three kingdoms. This attempt to understand the meaning of the Revolution through personal experience enjoyed a strong contemporary appeal: as Sharpe and Zwicker have argued, 'civil war and revolution not only and inevitably wrote and rewrote lives as texts of party and cause, they fashioned a desire, an appetite and market for lives, old and new, a market which printers and publishers rushed to satisfy'. ${ }^{13}$ In these writings, the life of each bishop 'also functions as an argument for episcopacy', but the argument, and hence the significance to be lent to the life, depended on context. Six lives of three bishops (William Bedell, John Bramhall and James Ussher), written between 1656 and 1686 , illustrate the shifting terrain of arguments about episcopacy (and

12 Conrad Russell, 'The British problem and the English Civil War', History, 72 (1986), 395-415; Russell, 'The British background to the Irish Rebellion of 1641', Historical Research, 61:145 (1988), 166-82 (both reprinted in Russell, Unrevolutionary England, 1603-1642 (1990), chs. 13 and 15); Russell, The Causes of the English Civil War: The Ford Lectures delivered in the University of Oxford, 1987-1988 (Oxford, 1990), especially ch. 2; Russell, The Fall of the British Monarchies, 1637-1642 (Oxford, 1991); Russell, 'Composite monarchies in early modern Europe: the British and Irish example', in Alexander Grant and Keith Stringer, eds., Uniting the Kingdom? The Making of British History (1995), pp. 133-46; J. H. Elliott, 'A Europe of composite monarchies', Past and Present, 137 (November 1992), 48-71. For John's use of the term 'dynastic agglomerates', see especially John Morrill, "Uneasy Lies the Head that Wears a Crown": Dynastic Crises in Tudor and Stewart Britain, 1504-1746, Stenton Lecture for 2003 (Reading, 2005).

13 Kevin Sharpe and Steven Zwicker, eds., Writing Lives: Biography and Textuality, Identity and Representation in Early Modern England (Oxford, 2008), p. 19, quoted by McCafferty below, p. 259. 
Ireland). These varying readings result perhaps in a paradoxical effect on the reader: 'Their very insistence on depicting their chosen bishops as exemplars of unity, piety, moderation and primitive episcopacy whose lives were played out in a discernible moral framework actually serves to highlight the traumatic uncertainties of the revolutionary years in the three kingdoms.' 14

A number of the other essays, following the lead offered by interpretations of the British problem or the crisis of three kingdoms, also offer new insight on the basis of a shift of geographical focus. Dagmar Freist (Ph.D. 1992) brings to an understanding of the responses to the royal marriage an awareness of the wider European debate about mixed marriage, and its dangers. That awareness puts the issues in a different light, just as it did for many contemporaries. Crucial here is the attempt to understand the practical context of political action - not just the categories of understanding that contemporaries appeared to find helpful, but the precise political context in which they were thinking and acting on that understanding, and how that transformed (or failed to) those initial categories. Freist explores how standard views of the dangers of Catholicism became attached particularly to the person of Henrietta Maria. This was an important element of the dangerous fusing of anti-popery (hostility to remaining corruption in the church) with fear of a Roman conspiracy against the English Church, and suspicion of actual Catholics. As a result, pressure was placed on the practical toleration of the Catholic minority which had characterized English life, despite the presence of virulent anti-popery in discussions of the English Church and polity. The question she addresses is how experience - news and rumour about Henrietta Maria and her political influence - served to put pressure on these everyday practices; how 'specific (subjective) experiences' led to a re-evaluation of pre-existing structures and values. Of central importance to this was awareness of the terms of the royal marriage contract, which reflected wider European expectations about the confessional rights and duties of those in religiously mixed marriages. Once they became public, these rights and obligations, formally extended to Henrietta Maria, fed into fears about the place of Catholicism in the English state and church. Mary Geiter (Ph.D. 1993) likewise demonstrates how ideas forged in one geographical context were subtly transformed by the transplantation to another. She charts the development of William Penn's thought from its grounding in a naval and republican context to its colonial expression in America. Again we see core commitments - to religious toleration, mercantile and imperial expansion - and an interest in constitutional

14 McCafferty, below, p. 269. 
solutions to political problems tested, shaped and reframed by the experience of revolution and, in this case, transplantation. Penn's vision was European and Atlantic in both inspiration and expression.

II

All three of these lines of interpretation - the localist, the religious and the British - remain central to John's work, and they were prominent themes in his 2006 Ford Lectures in Oxford. They are united into a coherent whole not only by the formation of John's particular interests but also by certain broader characteristics of his historical approach. Of these, perhaps the most pervasive and profoundly important is a preoccupation with individual personalities, motives and experiences. This impulse marked his earliest research in the field, informing his work on Cheshire. He has written of this retrospectively as deriving from his 'dissatisfaction with and revulsion against modelling of civil war allegiance on the basis of putting individuals into one of three boxes labelled royalist, parliamentarian and other, and then tipping out the contents of each box and looking for statistical variants between them'. ${ }^{15}$

This reaction against aspects of social scientific history was not uncommon during the 1970s and 1980s, even if it took a particular form among Stuart political historians. One recent account of the origins of 'the new cultural history', for example, identifies similar discontents:

In describing the behavioral tendencies of social groups and emphasizing normative behavior, often in the abstractions of numbers and charts, social historians had moved beyond an elite-dominated political paradigm, but had ignored both the uniqueness of individual experience and the ways in which social life is created through politics and culture. ${ }^{16}$

This is perhaps the core of John's critique of the field as he found it, for the historiography of the English Revolution had of course been profoundly influenced by some of the most distinguished practitioners of that kind of social scientific history. We have already noted John's early engagement with the gentry controversy and he himself has commented on how Lawrence Stone's Causes of the English Revolution (1972), a masterpiece of social scientific history writing, was important in crystallizing the dissatisfactions with the whole approach. ${ }^{17}$ While some of Stone's 'revisionist' critics subsequently engaged very explicitly with this cultural

15 Morrill, Nature, p. 180.

16 Paula S. Fass, 'Cultural history/social history: some reflections on a continuing dialogue', Fournal of Social History, 37: 1 (2003), 39-46, at 39, 40.

17 Morrill, Revolt in the Provinces, pp. 5-8, 17. 
history - most notably, of course, Kevin Sharpe - John seems instead to have continued to stick with the original question - to strive to explain and characterize the Revolution as a general phenomenon - but to do so in ways that do not do violence to, or ignore, the importance of immediate human experiences.

Certainly John has written with great sympathy about the practical difficulties and dilemmas of life during civil war and revolution, the ambiguous personal experiences and the choices made by active politicians and those facing the practical consequences of social and political conflict. The result is a picture of fluid and dynamic politics, rather than a clash between fixed blocks of ideas or interests, out of which come surprising alliances and commitments. His interest is not so much in the history of political thought, but the history of political thinking: he seeks to understand how personal and ideological commitments are given life in the difficult choices made by individuals understood in close context.

Much of John's most powerful and moving writing is in this mode, engaging with the beliefs and dilemmas of particular historical figures and the relationship between their public and private behaviour. Pride of place in this cast of characters must surely go to Oliver Cromwell, who emerges frequently and explicitly in John's bibliography from 1981 onwards. It was natural that John should write the life of Cromwell for the Oxford Dictionary of National Biography in 2004, subsequently reprinted in the 'Very Interesting People' series (2007). Few historians have written more hauntingly or eloquently than John about Cromwell's complex character and ambivalent achievement, in passages such as this:

What makes Oliver Cromwell endlessly appealing and endlessly alarming is that he was true to his own vision. He never doubted his call to service or to salvation... If God called upon him to be the human instrument of his wrath, he would not flinch. His sense of himself as the unworthy and suffering servant of a stern Lord protected him from the tragic megalomanias of others who rose to absolute power on the backs of revolutions. Cromwell's achievements as a soldier are great but unfashionable; as a religious libertarian great but easily mis-stated; as a statesman inevitably stunted. No one who rises from a working farmer to head of state in twenty years is other than great... He was to himself and to his God most true, if at great cost to himself and others. ${ }^{18}$

John likewise co-authored with Mark Kishlansky the ODNB life of Charles I, and that he should write equally compellingly about these two arch-enemies speaks volumes about the range of John's historical empathy. His ability to enter into the hearts and minds of historical figures is equally apparent with less prominent characters, ranging from

18 John Morrill, Oliver Cromwell (Oxford, 2007), pp. 121-2. 
the moderate William Davenport to the chillingly fanatical William Dowsing. This achievement expresses not only the power of John's historical imagination but also his capacity to engage empathetically even with those personalities most different from his own. John must surely, for example, be the first Roman Catholic deacon to have served as president of the Cromwell Association. A passionate interest in, and concern for, other people characterizes John's attitude towards both past and present. In terms of historical method, this comes through in his interest in historical biography: he not only contributed twelve lives to the $O D N B$ but also served as consultant editor for the over 6,000 seventeenth-century lives in that project.

Alan Orr's (Ph.D. 1997) study of John Lilburne's thought complements this approach by seeking to understand how his beliefs were shaped and formed by events, to recapture the 'complex, factionalized and ideologically messy' politics of the 1640 s, and the ideas to which that could give rise. On this reading, Lilburne's view of liberty arose not from an engagement with other thinkers addressing that question, nor from a formal education in the law, but from an 'ongoing, and sometimes subjectively reactive process'. In that process the conditions of his imprisonment exercised a crucial influence, as he drew creatively (although not necessarily with a full understanding) on the traditions of common law to develop a negative theory of liberty - liberty as the absence of active constraint, freedom from, rather than freedom to. Seen from this perspective Lilburne's political views appear as the product of a 'haphazard, goal-directed process undertaken with the practical aim of securing his release'. Orr presents this as a methodological corrective to historians of political thought, often more concerned with traditions, formal learning and intellectual context; here political thought is understood in dialogue with the very immediate and subjective experience of incarceration.

Perhaps the most dramatic personal experience of revolution was the kind of intense spirituality explored by Tom Webster (Ph.D. 1993). For John Gilpin, a Quaker, revolutionary religion was an immediate and physical experience, and the understanding of that experience was mediated by long-standing debates about the presence of the divine and diabolic in both the world and the body. Such experiences were highly contested, and stood close to the core of religious controversy, and it is difficult to understand the nature of this experience without close attention to the longer history of debates about possession and diabolism. As was so often the case, the authenticity of religious experience was contested in relation not to formal theology, or scriptural authority, but to a more pragmatic religious knowledge which was grounded in the everyday and the physical. Reports of these very direct and personal religious 
experiences were commonly the basis on which to redraw the boundaries of acceptable Christian practice or belief, and, Webster suggests, as that argument progressed in the accelerated conditions of revolutionary England, the terrain of those arguments shifted. The displacement of the possessed individual, and the details of the experience of possession, helped to inform the later denunciation of 'enthusiasm' or 'frenzy'. Here we can see, perhaps, an exemplary case for understanding the nature and consequences of the Revolution in terms of experience and its mediation.

It is hard to imagine a career more resistant to modern sociological categorization than that of Thomas Violet, described here by Ariel Hessayon (Ph.D. 1996). An English national of perhaps mixed ethnicity, marginal in some ways to the structures of respectable society, Violet nonetheless built up a considerable fortune and some impressive political connections. On the basis of these connections he sought to extort money from the semi-clandestine Jewish community in London. It is a deeply unappealing career, and in it the main political story of war and revolution appears as something of a backdrop, or a series of opportunities to be grasped, rather than a structuring feature of Violet's life and concerns. Instead, the sensitive reconstruction of his life reveals in fascinating detail dimensions of London's religious and commercial life that have previously been hidden. It prompts us to rethink the outlines of Anglo-Jewish history, our picture of London life, of international trade and its alliances, and the variety of experiences of revolution in midseventeenth-century London.

Michael Braddick's (Ph.D. 1988) essay explores these issues from the other end, by examining the difficulties of making particular languages work to describe new policies and changing conditions, and the problems that posed for securing and maintaining allegiance. He shows how the pressures of the Parliamentarian mobilization for the first year of the real war in 1643 revealed the limitations of arguments as they were first promoted in opposition to royal policies during the $1630 \mathrm{~s}$, and how this prompted some individuals to re-examine their allegiance and to clarify their original commitments. But this instability in political language was also an opportunity to redefine standard forms of political argument in creative ways: the tension between a commitment both to standard political languages and to the innovations necessary to achieve political victory was an important context for intellectual creativity, one way of addressing the origins of revolutionary politics.

This view of ideas in motion, and the relationship between concepts and languages, also characterizes James Hart's (Ph.D. 1985) essay which explores the fate of two notions of Parliament as a Great Council as the political crisis unfolded. There were medieval precedents both for 
a notion of a baronial council of the king and also for the view that Parliament as a collective body was the Great Council: a Great Council in Parliament and a Great Council of Parliament, as it were. There were some tensions between these notions and, in any case, neither justified the executive role that Parliament had begun to claim by the time of the Ten Propositions in June 1641. The baronial notion was rendered obsolete under the pressure of events, and the notion of Parliament as the king's Great Council transformed almost beyond recognition. By October 1643, when the Commons secured the Lords' acquiescence to the issue of a Great Seal under its own authority, neither the baronial nor the monarchical element seemed crucial to the notion of the Great Council. This new claim about the constitutional and political role of Parliament apparently justified its position as an executive authority.

Jonathan Scott (Ph.D. 1986) returns to Harrington's Oceana in a similar spirit, placing it in the context of the search for settlement in 1656 . Clearly articulated from within the traditions of humanism, or classical republicanism, Oceana was, nonetheless, a response to immediate conditions. The difficulty faced by successive attempts at settlement was not to do with their betrayal of principles or the cause so much as their failure to identify the necessary basis for political stability. The same was true of Hobbes's Leviathan, another work of theory with an immediate political purpose. Here the experience of conflict and constitutional stability sharpened Harrington's theoretical understanding of both the classical tradition that he inherited and the structures of the society he inhabited. Once again, ideas are most richly understood through a reconstruction of the specific personalities and circumstances of their exponents.

Many of the other essays here pursue the meanings of the Revolution through an understanding of individual experiences - notably those by Burgess, Smith, Freist, Geiter and McCafferty. For John, these attempts to understand individual experiences of the Revolution are central to the attempt to characterize its nature. In his treatment of individuals, John has sought to understand not just what was pliable but also what was not what persisted or proved fundamental. This is crucial to his underlying view of historical change. So, for example, in one essay he drew an analogy that had become familiar to many of his students, that of the 1862 Solera Madeira kept in the cellar of his Oxford college. Every year a part of the vat is drawn off and another cask of wine is added, so that the wine drawn off each year is 'always developing and changing as the older vintage matures and the younger wine adds its own distinctive flavor'. ${ }^{19}$ And,

19 'John Morrill', in Juliet Gardiner, ed., The History Debate (1990), pp. 90-5, quotations at pp. 90, 91-2. 
we might add, although the identity of the whole is consistent, its actual composition is in continuous evolution. Historians, then, are dealing with 'the process of becoming', and that is best understood through the experiences of individuals wrestling with the dilemmas of an engaged political life. This is the real core of his response to the limitations of the impersonal categorizations that drove the social scientific history of the 1950s and 1960s. Putting 'individuals into ... boxes' with simple labels not only fails to do justice to the complexities of their lives, but in so doing it limits our understanding of the nature of the Revolution. ${ }^{20}$

\section{III}

Throughout his academic career, John has been pre-eminently concerned with the lives and experiences of human beings, with their hearts and minds, their aspirations and sufferings: with the experience of revolution as a key to understanding its nature. This is the underlying concern which unites the essays in this volume, all of them written by John's students: the presumption that to understand the causes, trajectory and consequences of the Revolution we must understand it as a human and dynamic experience, as a process. Of course, as McCafferty points out, 'Individual experience, no matter how well contextualized nor how brilliantly articulated, can do no more than offer partial, if often vivid, insight'. ${ }^{21}$ But an understanding of these personal experiences is certainly an important part of any attempt to define the nature of the Revolution, and can provide the basis on which to build up larger frameworks of interpretation. This has been John Morrill's project and while many of these authors disagree with him on the detail and pertinence of the larger frameworks he has proposed, they are all, in this more fundamental respect, following in his footsteps. They are profoundly conscious of the debt that they owe to his inspiration and example.

20 The quality of imaginative empathy also characterizes John's sensitive, generous and candid appreciations of other historians in his field. This gift first became apparent in 1983, when he co-edited a collection of papers by his former tutor at Trinity College, Oxford, J. P. Cooper; this volume included John's essay on 'J. P. Cooper as a teacher'. Since then, John has written at length, often for the British Academy or the ODNB, about scholars as diverse as Christopher Hill, J. P. Kenyon, Austin Woolrych and Conrad Russell. These memoirs all display a compelling evocation of personality and a generous but not uncritical assessment of the subject's achievements as a historian. It is typical of John that his concern with the political and religious psychology of seventeenth-century people is combined with a similar desire to enter into the mindset of those scholars who have studied them.

21 McCafferty, below, p. 269. 